Biol. Neonate 1986;49:I-VI

\title{
Contents, Vol. 49, 1986
}

\section{Contents Vol. 49,1986}

\section{No. 1 Original Paper}

Evolution of the Barrier Effects against an Exogenous Drug-Sensitive Escherichia coli Strain after Single or Repeated Oral Administration to Newborns and Infants Aged up to Three Months Admitted to an Intensive-Care Unit

Poisson, D.M.; Borderon, J.C.; Amorim-Sena, J.C.; Laugier, J 1

Perinatal Effects of Nicotine

Nasrat, H.A.; Al-Hachim, G.M.; Mahmood, F.A 8

Plasma Prolactin Levels in Full-Term Newborn Infants with Idiopathic Edema: Response to

Furosemide

Ertl, T.; Sulyok, E.; Bódis, J.; Csaba, I.F 15

Hemodynamic Effects of High Frequency Ventilation in Surfactant-Treated Preterm Lambs

Oguchi, K.; Baylen, B.G.; Ikegami, ML; Jacobs, H.; Berry, D.; Jobe, A.; Emmanouilides, G.C. 21 Effect of Acidosis and Hypoxia on Intestinal Blood Flow of Sheep Fetus

Younoszai, M.K.; Kisker, T.; Robillard, J.; Nathan, R

The Effect of Dexamethasone and Surgically Induced Intrauterine Growth Retardation on Renal and Hepatic Levels of Phosphoenolpyruvate Carboxykinase in the Rat

Levitsky, L.L.; Edidin, D.V.; Menella, J.A.; Spaulding, N.H.; Hsieh, L.-C 36

Quantitative Studies on the Fetal Lipid Metabolism in Rats: Liver Fatty Acid Esterification and Conversion into Carbon Dioxide, and Hepatic Output of Triglycerides and Phospholipids into Serum

Zimmermann, T.; Hummel, L.; Wagner, H 43

Effects of Streptozotocin Injection into Fetal Rabbits on Their Subsequent Growth in utero Fletcher, J.M.; Bassett, J.M 51

Acknowledgements 60

No. 2 Original Paper

Thrombopoietic Activity in Newborn Infants

Bessler, H.; Sirota, L.; Weissman, Z.; Dulitzky, F.; Djaldetti, M 61

Circulatory Changes in Fetuses with Imminent Asphyxia

Lingman, G.; Laurin, J.; Marsãl, K 66

Development of the Epidermis in the Newborn

Evans, N.J.; Rutter, N 74

Amniotic Fluid Retinol Concentrations in Late Pregnancy

Koskinen, T.; Valtonen, P.; Lehtovaara, I.; Tuimala, R

Fetal Growth Retardation in Rats from Different Levels of Hypoxia

de Grauw, T.J.; Myers, R.E.; Scott, W.J

85

IV Contents

Unconjugated and Conjugated Bilirubin Pigments during Perinatal Development. I. Studies on Rat Serum and Intestine 
Muraca, M.; Blanckaert, N.; Rubaltelli, F.F.; Fevery, J 90

Activities of Enzymes Associated with the Metabolism of Glutathione in Fetal Rat Liver and Placenta

Di Ilio, C; Del Boccio, G.; Casalone, E.; Aceto, A.; Sacchetta, P 96

Metabolic Effects of Endotoxin in Newborn Rabbits

Molnár, D.; Székely, M 102

Generation of Leukotrienes from Fetal and Neonatal Porcine Blood Vessels

Piper, P.J.; Levene, S 109

Physiologically Elevated Concentration of Serum Trypsin-Like Immunoreactivity in New-

borns. Comparison with Lipase

Carrère, J.; Estevenon, J.P.; Guy-Crotte, O.; Thouvenot, J.P.; Figarella, C 113

No. 3 Original Paper

Body Composition at Birth of Growth-Retarded Newborn Infants Demonstrating Catch-Up

Growth in the First Year of Life

v.d. Wagen, A.; Okken, A.; Zweens, J.; Zijlstra, W.G

Development of Serum Hexosaminidase Activity in Infants

Shattuck, K.E.; Richardson, C.J.; Rassin, D.K.; Lobe, T.E 126

Renal Bicarbonate Handling in Low Birth Weight Infants during Metabolic Acidosis

Zilleruelo, G.; Sultan, S.; Bancalari, E.; Steele, B.; Strauss, J

132

Relationship between Liver Glycogen Metabolism and Glucose Homeostasis in the Fetal

Rat: Studies with the gsd/gsd Rat

Gain, K.R.; Watts, C 140

Teratogenic Effect of Semicarbazide in Wistar Rats

de la Fuente del Rey, M 150

Ontogenesis of the Kidney in the Congenital Hypothyroid Rat. Biochemical and Anatomical Parameters of General Development

Ali, M.; Clos, J 158

2-14C-Mevalonate Oxidation during Rat Development

Hahn, P 168

Placental Blood Flow and Fetal Weight following Uterine Artery Ligation. Temporal

Aspects of Intrauterine Growth Retardation in the Guinea Pig

Jansson, T.; Thordstein, M.; Kjellmer, 1172

No. 4 Original Paper

Relationship between Glucose Utilization Rate and Glucose Concentration in Preterm

Infants

Zarlengo, K.M.; Battaglia, F.C.; Fennessey, P.; Hay, W.W.. Jr 181

Developmental Variations in CSF Monoamine Metabolites during Childhood

Hedner, J.; Lundell, K.H.; Breese, G.R.; Mueller, R.A.; Hedner, T 190

Interaction between Nonnutritive Sucking and Respiration in Preterm Infants

Paludetto, R.; Robertson, S.S.; Martin, R.J 198

Net Transfer of Essential Metals from Mother to Fetus in the Second Half of Pregnancy in the Rat

Romeu, A.; Alemany, M.; Arola, L 204

Contents V

Growth and Differentiation of Fetal Rat Intestine Transplants: Dependence on Insulin and Growth Hormone 
Cooke, P.S.; Yonemura, C.U.; Russell, S.M.; Nicoll, C.S 211

Adrenal Phenylethanolamine-N-Methyltransferase Activity in the Young Rat: Influence of Thyroid Hormones and Insulin-Induced Hypoglyce-mia

Gripois, D.; Valens, M 219

Ultrastructure of Insulin Secretory Granules and Insulin Content of Fetal Pancreas Exposed to Ethanol in utero in the Rat

Singh, S.P.; Yokoo, T.; Yokoo, H.; Snyder, A.K.; Singh, S.K 224

Intestinal and Femoral Blood Flow Autoregulation in Developing Swine

Buckley, N.M.; Brazeau, P.; Frasier, I.D 229

Announcement 240

No. 5 Original Paper

Qualitative and Quantitative Aspects of Human Fetal Liver Metallothioneins

Clough, S.R.; Mitra, R.S.; Kulkarni, A.P 241

The Effects of Glycolipids and Carbohydrates on Bilirubin Cytotoxicity in vitro

Sugita, K.; Sato, T.; Fuse, A.; Nakajima, H 255

Neuroleptic Drug-Induced Alterations on Neonatal Growth and Development. I. Prenatal

Exposure Influences Birth Size, Mortality Rate, and the Neuroendocrine System

Ching, M.; Tang, L 261

Polysomnograms and Cardiopneumograms in SIDS Research

Flores-Guevara, R.; Lacombe, J.; Monod, B.; Bernhard, N.; Guidasci, S.; Monod, N. . 270

Chronic Caffeine Intake by Rat Dams during Gestation and Lactation Affects Various Parts of the Neonatal Brain

Nakamoto, T.; Hartman, A.D.; Miller, H.I.; Temples, T.E.; Quinby, G.E., Jr

Body Weight and Brown Fat Activity in Hyperphagic Cafeteria-Fed Female Rats and Their Offspring

Rothwell, N.J.; Stock, M J 284

Proteinase Inhibitors in the Gastrointestinal Tract, Pancreas and Liver during Fetal and

Postnatal Development of the Pig

Ohlsson, B.G.; Weström, B.R.; Karlsson, B.W 292

No. 6 Original Paper

Postprandial Thermogenesis in Human Milk-Fed Very Low Birth Weight Infants

Rubecz, I.; Mestyán, J301

Levels of Growth Hormone and Growth-Hormone-Releasing Factor in Cord Blood

Nagashima, K.; Yagi, H.; Suzuki, S.; Noji, T.; Yunoki, H.; Kuroume, T 307

Intrauterine Anoxic Brain Damage in Nonimmune Hydrops fetalis

Kobori, J.A.; Urich, H311

Functional and Ultrastructural Studies of Granulocyte Adherence in the Newborn

Algarra, S.M.; Devesa, M.G.; Remohi, J.; Dy, C; Gonzalez, J 318

Regional Variations of Iodine Nutrition and Thyroid Function during the Neonatal Period

in Europe

Delange, F.; Heidemann, P.; Bourdoux, P.; Larsson, A.; Vigneri, R.; Klett, M.; Beckers, C; Stubbe, P 322

VI

Contents

5'-Nucleotidase Activity in Adult and Fetal Rabbit Lungs

Tsao, F.H.C 331 
Correlative Study on Sex Differences in Pituitary Luteinizing Hormone Content and the Number of Immunoreactive Luteinizing Hormone Cells in Perinatal Rats

Watanabe, Y.G 337

Isolated Pancreatic Acini from Suckling and Weanling Rats: Changes in Amino Acid Incor poration and Carbachol-Stimulated Amylase Secretion with Age

Pollack, P.F.; Verbridge, J.; Thornburg, W.; Koldovsky, O.; Korc, M

344

Announcement

350

Author Index 351

Subject Index 353 